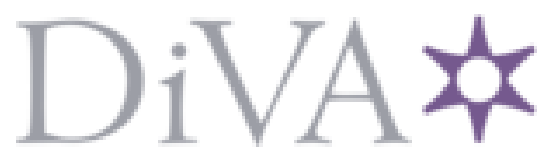

http://www.diva-portal.org

This is the published version of a chapter published in Visions of North in premodern Europe.

Citation for the original published chapter:

Langum, V. (2018)

Cold characters: Northern temperament in the premodern imaginary

In: Dolly Jørgensen and Virginia Langum (ed.), Visions of North in premodern Europe (pp. 123-144). Brepols

Cursor Mundi

https://doi.org/10.1484/M.CURSOR-EB.5.114060

N.B. When citing this work, cite the original published chapter.

Permanent link to this version:

http://urn.kb.se/resolve?urn=urn:nbn:se:umu:diva-143119 


\title{
COLD CHARACTERS: NORTHERN TEMPERAMENT IN THE PREMODERN IMAGINARY
}

\author{
Virginia Langum
}

$\mathrm{T}$

here is nothing particularly premodern about associating climate with character or disposition. After the identification of seasonal affective disorder in the 1980s, scientists correlate mood changes to the absence of light in winter months. ${ }^{1}$ Other studies tie more specific kinds of behaviour to specific climates, such as violence to heat. ${ }^{2}$ Most recently, a new study predicts a startling increase in violent crimes related to global warming. ${ }^{3}$ Indeed, throughout past millennia, attempts to link temperament and temperature form a persistent 'moral climatology."

${ }^{1}$ Partonen and Magnusson, Season Affective Disorder.

${ }^{2}$ Some of these studies reflect or confront common cultural assumptions. For example, in response to common assumptions that higher temperatures lead to more violence in the American South, one influential study, Culture of Honor, rejects this climatic theory, while advancing another materialistic theory: that coristol and testosterone levels are elevated in Southerners when provoked far beyond that of their Northern peers. See Nisbett and Cohen, Culture of Honor, pp. 3, 22, 82-84. See also Van de Vliert and others, 'Temperature, Cultural Masculinity, and Domestic Political Violence'.

${ }^{3}$ Ranson, 'Crime, Weather and Climate Change'. The study garnered a lot of criticism, leading researchers to evaluate similar studies for flaws. The resulting working paper published by the National Bureau of Economic Research deemed fifty-six of these studies correlating climate change and violence valid. Burke, Hsiang, and Miguel and others, 'Climate and Conflict'.

${ }^{4}$ Livingstone, 'Race, Space and Moral Climatology'. Examples in this volume of linking

Virginia Langum is associate professor of English literature at the Department of Language Studies at Umeå University and Pro Futura Scientia Fellow at the Swedish Collegium for Advanced Study at Uppsala University. 
In ancient thought, medical and naturalistic theories of airs, waters, and places attributed particular physiologies to particular climates. ${ }^{5}$ Temperature, humidity, and other geographical factors were thought to influence the balance of the four humours, or the major four bodily fluids: choler, blood, phlegm, and melancholia. This balance correlated to physical, moral, and intellectual traits. ${ }^{6}$ Such climate theory occurs in texts from ancient Greece well into eighteenth-century Europe. ${ }^{7}$

While scholarship has discussed climate theory at length in relation to early modern thought and literature, it is patchier in regards to medieval thought. ${ }^{8}$ Medieval authors are deemed repetitive and derivative of their Greek and Arabic sources or they are skipped over altogether in chronological accounts ranging from ancient Greece to early modern Europe. ${ }^{9}$ However, several recent contributions to medieval studies have emphasized climate theory or 'geohumoralism' - as a significant lens through which medieval thought understood differences between groups of people, arguing that climate theory contributes to proto-racialist thought. ${ }^{10}$ There is a robust debate about whether race and racism are productive categories through which to consider medieval thought. ${ }^{11}$ The debate centres upon how medieval thought understood differences between groups, whether difference is an essential, material, biological matter, or whether difference is more culturally conceived, with groups bounded by language, law, conventions, and customs. ${ }^{12}$ Climate theory,

climate and temperament/behaviour in early modern literature include de Angelo, 'Making Saami of the Scots', and Ballester Rodríguez, 'Unknown and Barbarian'.

${ }^{5}$ Glacken offers a comprehensive account of the relationship between man and the natural environment in the history of thought in Traces on the Rhodian Shore.

${ }^{6}$ Langum, Medicine and the Seven Deadly Sins.

7 Beller, 'Climate'.

${ }^{8}$ Some early modern studies include Floyd-Wilson, 'Temperature, Temperance, and Racial Difference', Wands, 'The Theory of Climate', and Tooley, 'Bodin and the Medieval Theory of Climate'.

${ }^{9}$ Hogden, Early Anthropology; Glacken, Traces on the Rhodian Shore, p. 255; Zacharasiewicz, 'The Theory of Climate and the North'; Beller, 'Climate'.

10 The term has been used by both early modern and medieval scholars to describe the same phenomenon. See Floyd-Wilson and Sullivan, Environment and Embodiment in Early Modern England, p. 5; MacInnes, 'Altering a Race of Jades'; Cohen, 'Race', pp. 118, 121.

${ }^{11}$ See Heng's 'The Invention of Race in the European Middle Ages I' and 'The Invention of Race in the European Middle Ages II'.

${ }^{12}$ For the former theory, see Cohen, 'On Saracen Enjoyment', pp. 115-18; for the latter 
which offers a material explanation for perceived essential differences, is critical to this discussion.

While there is not space to adequately explore the category and concept of race in premodernity, this essay explores how vital climate theory is to premodern discussions of 'northernness'. Is northern character innate? A focus on England is a useful lens for gauging conceptions of northernness. Described in more detail below, traditional climate theory disparages extreme climates, both northern and southern. Thus, English writers may have had a distinct interest in responding to such claims about northern character either by distancing England from negative descriptors of the 'northern character' and the North itself or by reformulating and reassigning northern physiology. In what follows, I briefly sketch the ancient and medieval context for climate theory before examining how key encyclopaedic and historical works from the early modern and late medieval periods describe northernness and how they map England in relation to northernness. While it might seem counterintuitive to move from early modern back to medieval, the strong climatic tenor of the early modern context writing illuminates the differences and absences of argument in the later medieval texts. I provide Modern English translations throughout, which are my own unless otherwise indicated in the footnotes.

\section{Temperature and Temperament in Ancient and Medieval Thought}

According to ancient medicine, climate affected complexion, which referred to the internal balance of the elements cold, hot, wet, and dry. The human body exhibited external markers of internal complexion such as skin colour and porosity, hair thickness, and fleshiness. The balance of elements also affected what we might describe as 'temperament' - outlook, character, and disposition to act and think in certain ways - however, temperament referred not only to behavioural nature but also to physiology.

While geography and climate strongly impacted the behaviour and character of groups, there were other contributing factors. The Hippocratic Airs, Waters, Places and other texts in this tradition argue that law can artificially counteract nature, for example. ${ }^{13}$ Furthermore, some physiological and char-

theory, see Bartlett, 'Symbolic Meanings of Hair in the Middle Ages', which examines how hair 'was used to mark status, ethnic identity, age and sex' (p. 44).

${ }^{13}$ Isaac, 'Racism', p. 40. 
acter traits have cultural causes. For example, the northern Scythians are more likely to be sterile from their long periods of horseback riding. ${ }^{14}$

Later Arabic thinkers and commentators, such as Avicenna (d. 1037) and Haly Abbas (d. 994), also provided medical explanations corresponding to accepted geo-climatic differences between peoples. The cold and dry southerners were intelligent but weak, and the hot and wet northerners were stupid and strong. External heat drew moisture out of the body, opening the pores and causing the body to lose both internal heat and moisture in the process. Likewise, external cold prompted the body to close the pores, trapping internal heat and moisture in the body. The moderate temperature of the middle zone between north and south facilitated the ideal, moderate temperament of its inhabitants.

As it had done for other areas of natural philosophy, the translation and transmission of Arabic and Greek texts beginning in the twelfth century also spurred interest in the relation between climate and disposition. In the Middle Ages and early modern period, climate theory provided a framework not only for explaining the differences between people but also for determining the best way to govern. Such is the rationale for De regno (On Kingship) by Thomas Aquinas (d. 1274) that confirms ideas of northern insufficiency based on physiological grounds. Drawing from the pseudo-Aristotelian Problemata, Aquinas claims that northerners are stupid and blood-thirsty owing to their 'largo sanguine redundantes' (ample flow of blood). ${ }^{15}$

The German Dominican Albert the Great, or Albertus Magnus (d. 1280), offers a more extensive treatment of climate theory. His De natura locorum (On the Nature of Places) attributes material implications of climate upon human bodies and characters. Following tradition, Albert divides the whole the world into seven climes correlating to the seven planets. The first and seventh climes are the most extreme, the coldest and hottest respectively, the second and sixth are slightly less so but close to the first and seventh, and the fourth and fifth are most temperate and healthy.

Like many of his contemporaries and future commentators on climate, Albertus adopts the term 'Scythian' to describe northern peoples in both Asia and Europe. Albertus held with ancient ideas about the heat of northern bodies in the higher climes and the cold of southern bodies in the lower climes facilitating unsavoury character traits whereas the temperate middle climes

\footnotetext{
${ }^{14}$ Glacken, Traces on the Rhodian Shore, p. 86.

15 Aquinas, De regno ad regem, II.2.
} 
supported more temperate characters. For example, he writes, that northern customs are 'wolfish on account of the heat in their hearts' whereas southerners are 'light-hearted'. Those in between 'easily cultivate justice, keep their word, embrace peace, and love the society of men. ${ }^{16}$ Furthermore, he describes the northern disposition to impetuosity and lack of discretion, citing the same ancient Roman text as Aquinas.

How essentialist were these climatic traits in medieval medicine? Was nature intractable? Medieval physiognomic texts distinguish between natural complexion, subject to change based on a change in environmental and other accidental factors, and radical complexion as the innate complexion of a person. Yet this innate complexion also could be altered. Ideal complexions were, furthermore, relative to particular climates. A healthy complexion in a southern climate could lead to disease and death in a northern climate and vice versa. Humoral balance adapted to new climates and thus their markers also altered. Even skin colour could change. ${ }^{17}$ Accordingly, Albertus is not deterministic in his climate theory. Rather, he suggests that the composition of the body might alter within a few generations of moving to another climate and region. He not only describes how plants and animals become smaller or larger when they are moved to another climate, but also conjectures that if Ethiopians were to relocate, within a few generations, their skin would be fairer. ${ }^{18}$

\section{England and Northernness in Early Modern Thought}

While Aquinas and Albertus write broadly about climates in terms of cardinal directions, other texts provide a more precise geographical span of populations. A focus on one particular land and people - England and the English - and their relationship to northernness reveals how significantly writers from the early modern and medieval period conceived of and integrated climate theory. Historically, England was marginalized in geographical writings in the ancient world, in the words of one scholar, 'a global other. ${ }^{19}$ Not only was England geographically separate from the continent, but in Greco-Roman tradition, it was considered to have a climate on the margins, oikoumene (uninhabitable). ${ }^{20}$ In

\footnotetext{
16 Tilman, An Appraisal of the Geographical Works of Albertus Magnus, p. 105.

17 Ziegler, 'Physiognomy, Science and Proto-Racism, 1200-1500', pp. 193-95.

${ }^{18}$ See Bartlett, 'Medieval and Modern Concepts of Race and Ethnicity', p. 47.

${ }^{19}$ Lavezzo, Angels on the Edge of the World, p. 3.

${ }^{20}$ Lavezzo, Angels on the Edge of the World, p. 60.
} 
his commentaries on Sacrobosco's De sphera mundi (1271), Robert Anglicus summarizes: 'the last clime ends [...] hardly across the English channel, so that almost all England is outside a clime.' ${ }^{21}$ So England's status as Northern is somewhat debatable, a position that could be exploited by writers depending on their perspectives and desired position to the North.

Likely influenced by the expansion and colonization of European states in the sixteenth century, texts relating to national difference and geography greatly multiplied in the sixteenth and seventeenth centuries. Early modern writers inherited thought regarding northern temperament from those ancient and medieval authorities cited previously as well as from newly translated ancient texts. ${ }^{22}$ Here I examine two historical works in relation to the theme of northern character and England as a background to compare medieval texts on England and northern character: Methodus ad facilem historiarum cognitionem (Method for the Easy Comprehension of History, hereafter Method) by the French Jean Bodin (d. 1596) and the compilation of texts by various authors but often associated with Raphael Holinshed (d. 1580) Chronicles of England, Scotland and Ireland.

Following Aristotle and Aquinas, Bodin argues that in order to determine the best systems of governance, an understanding of the natural differences between peoples is necessary. Furthermore, he also deemed such knowledge critical to evaluate historical events. Within the context of his widely distributed and read Method, the temperate zone includes Bodin's own homeland, France, as well as Italy, Upper Germany, and parts of Spain. Among the closest Southerners are the Sicilians, Arabs, Cretians, Moors, and other Spaniards. The North is divided in to the extreme north of northern Scandinavia, to which Bodin does not devote much commentary, and the nearer north of Denmark, Lower Germany, England, and Scotland ${ }^{23}$ His climate theory reflects that of the ancients, with cold climates ensuring 'igitur vis interni caloris' (the strength of inward heat) of those who live in northern lands, thus making them 'vegetiores ac robustiores sint Australibus' (more active and robust than the southerners). ${ }^{24}$ This biological drive explains the historical narrative of empires tending to

${ }^{21}$ Quoted in Knapp, An Empire Nowhere, p. 271 n. 57.

22 These texts often included and responded to newly translated classical texts, such as Caesar's Commentaries and Tacitus's Agricola and Germania, which concerned the expansion of Rome into northern Europe. See Feerick, 'A “Nation...Now Degenerate”, p. 35.

${ }^{23}$ Method for the Easy Comprehension of History (hereafter Method), ed. by Reynolds, p. 96.

${ }^{24}$ Bodin, Methodus ad facilem historiarum cognitonem, p. 86. English from Method, p. 92. 
spread southward and seldom northward, as well as the English victory over the French and, in turn, Scottish victories over the English. ${ }^{25}$ Within geographical gradations there are obvious physiological and psychological gradations, an increasing internal warmth from France to England to Scotland which impacts the course of history.

Bodin seeks humoral explanations for behaviour at every opportunity, even for those which the ancients did not. For example, where Caesar wrote that Germans are tall and strong because they 'animi libertate fruerentur, nec honestis disciplinis am puero imbuerentur' (enjoy liberty of will and are not shaped by a liberal education from boyhood), Bodin insists that 'cum tamen id calori \& humori tribuendum sit' (their growth really ought to be attributed to heat and humour). ${ }^{26}$ Method particularly focuses on the northern predilection towards drunkenness and its biological basis. Where Tacitus observed northern drinking habits, he omitted the natural causes. ${ }^{27}$ Bodin explains that the natural heat of the Northerners creates a great appetite for wet and cold, quenched in their drinks. ${ }^{28}$ So strong is the physiological urge to drink that it 'vllis vnquam temporibus aust legibus potuit emendari' (can never be changed at any time or by any laws). ${ }^{29}$

Biology also explains northern barbarism. Throughout history, tyrants have long employed Northerners as bodyguards due to their strength and lack of 'cunning and malice', qualities Bodin associates with civilization. The farther one is from human culture, that is, from the nature of men, the nearer he approaches to the likeness of beasts, which since they are lacking in reason, are unable to restrain their wrath and appetites. So it happens that the Northerners are carried by impulse into acts of cruelty. ${ }^{30}$ Yet Bodin insists that the Southerners are actually 'multo crudeliores' (much more cruel) than Northerners. ${ }^{31}$ Owing to their physiological dispositions, the quality of their anger is different than that of the Northerners. The hot, choleric Northerners are prone to short passionate outbursts whereas the cold, melancholic Southerners are prone to simmering, premeditated acts of revenge. ${ }^{32}$

25 Method, p. 93.

26 Bodin, Methodus ad facilem historiarum cognitonem, p. 87. English from Method, p. 94.

27 Method, p. 95.

28 Method, p. 94.

${ }^{29}$ Bodin, Methodus ad facilem historiarum cognitonem, p. 87. English from Method, p. 94.

30 Method, p. 99.

${ }^{31}$ Bodin, Methodus ad facilem historiarum cognitonem, p. 93. English from Method, p. 101.

32 See Langum, 'Sacred and Secular Wrath', pp. 27-34. 
Given these strong natural compulsions, are Northerners culpable for certain vices, such as drinking, at all? In Bodin's conception, northern and southern dispositions represent two poles: the body and the soul. The greater strength of the northern body means that their intellects are weaker, impacting their free will and ability to modify their actions against the pulls of nature: 'ab in opia rationis \& confilii Septentrionales appetitum cohibere nequeunt, ac prepterea intemperantas' (from want of reasoning and wisdom Northerners cannot control their appetites). ${ }^{33}$ Where the strength of the body is greater than that of the soul, the soul cannot be expected to can dominate. Thus whereas, Southerners are culpable for drunkenness, Northerners are not, as they 'se cohibere non facile possint, cum vrgeantur ab interior calore $\&$ ingenij viribus deserantur' (cannot easily restrain themselves even if they wished, for they are impelled by internal warmth and lack the resources of genius). ${ }^{34}$

Likewise, Bodin argues Northerners are not to be praised for their continence as his ancient sources did. While more fertile, Northerners are not inclined to lust as are Southerners, 'quod tamen continentia tribui nullo mollo potest, cum antea docuerimus Septentrionales suapte natura intemperatissimos esse in poru, cibo, ira, alea, rapinis' (yet this can in no way be attributed to selfcontrol, since we have already shown that the northerners, by their own nature, are most intemperate in drinking, food, wrath, gaming, and stealing)..$^{35}$ There is no virtue where there is no temptation. He adds, presumably referring to northern prowess, 'vt nemo fortis dici possit, nulo proposito periculo vel labore' (no one can be said to be brave when no danger or toil has been confronted). ${ }^{36}$

Despite the heavy materialism of the text, Bodin ultimately attempts to assert the transcendence of free will over climatic dispositions. First, there is the possibility of mingling and migration. Of the first, the impact of fusion of peoples changes both external and internal markers. Bodin points to the increasing physical homogeneity as one travels further from the temperate zone in either direction, owing to the great number of peoples moving towards the temperate area. As for character development, he lists a few examples of how Northerners - Danes, Saxons, and English - integrated their bravery into the more southern Britons while they themselves became more kind. ${ }^{37}$ The quality

33 Bodin, Methodus ad facilem historiarum cognitonem, p. 93. English from Method, p. 101.

${ }^{34}$ Bodin, Methodus ad facilem historiarum cognitonem, p. 118. English from Method, p. 128.

${ }^{35}$ Bodin, Methodus ad facilem historiarum cognitonem, p. 97. English from Method, p. 105.

${ }^{36}$ Bodin, Methodus ad facilem historiarum cognitonem, p. 97. English from Method, p. 105.

${ }^{37}$ Method, p. 144. 
of this change is left unexplained - whether it is a sociocultural shift or a more constitutional change. Given the previous discussion and comparison of people to plants who 'quickly lose their identity and adapt themselves to the nature of the soil whence they take their nourishment', we can assume that Bodin refers to a more physiological change. This is reinforced by his brief discussion of 'training' as a distinct category by which peoples can change. However, both these possibilities - mixing and training - are dwarfed by the prolific evidence Bodin presents for how physiological determinants shape the characters of people in particular geographical regions.

Bodin was incredibly influential and popular in England. ${ }^{38}$ How did these barbaric Northerners respond to such descriptions of themselves? A text involving the work of several authors and compilation of older authorities, Chronicles of England, Scotland and Ireland responds to ancient and contemporary critiques of the North, particularly England, both by reconfiguring the location of the North and revising the conception of the North. I cite from the 1587 version of the text. ${ }^{39}$

Chronicles relocates the North to Scotland, displacing negative associations of the North away from the English and onto the Scots, 'a people mixed of the Scithian and Spanish blood' and appropriately the 'most Scithian-like and barbarous nation' of the British Isles. ${ }^{40}$ Traits associated with northernness, such as gluttony, are also deflected onto the Scots. The Scots far exceed the English in 'distemperate gormandiz(ing)'. ${ }^{41}$ Chronicles also emphatically distances the 'wild Irish' and their customs from the English, adding that the inhabitants of the English pale in Ireland. ${ }^{42}$

Furthermore, Chronicles argues against tarring the English with certain stereotypes of Northerners, such as inferior intelligence. Or, as the text characterizes the argument of 'the foreign historiographers', 'because we dwell northward, we are commonly taken [...] to be men of great strength and little policy', meaning that their brains are not as heated by ample exposure to the sun. Chronicles argues, however, that the days are quite long in England compared to the rest of North. Indeed, England is even more temperate than

38 Dean, 'Bodin's “Methodus” in England before 1625' traces to references to Bodin by English authors from its publication until the first quarter of the seventeenth century.

${ }^{39}$ Holinshed, Chronicles of England, Scotland and Ireland (hereafter Chronicles).

40 Chronicles 1.4 .

41 Chronicles 3.6.

42 Chronicles 1.8 . 
France in the summer. ${ }^{43}$ Chronicles' response to traditional climate theory in general and to Bodin in particular is clear. Bodin's Method is cited directly in the text numerous times.

Yet for the compilers of Chronicles, it was clearly not enough to refute the climatological theories behind the maligning of the English. Instead, the text develops a conceit that explains the degeneration of the English through luxury imports, an early argument against the effects of globalization on local health. The text claims that 'north Britons' are getting fat from southern European imports. Despite being 'indued with an excellent nature', the northern body cannot cope with the introduction of foreign foods. Given that these foreign imports cause sicknesses and vices, Chronicles advocates a return to old mores and sensibilities, which are supported and sustained by the climate. ${ }^{44}$

From these two texts, Method and Chronicles, we take a sense of a carefully delineated North. This is important due to the negative character traits associated with each region and their intractability. The English-produced Chronicles directly responds and refutes claims against the English, suggesting the extent to which these ideas were taken seriously.

\section{England and Northernness in Medieval Texts}

How do medieval texts present England and Englishness in relation to the North and northernness? For their extensive descriptions of many countries, including England, two works are particularly instructive: De proprietatibus rerum (On the Properties of Things) of Bartholomaeus Anglicus (d. 1272) and the Polychronicon of Ranulf Higden (d. 1364). Translated into several vernacular languages, On the Properties of Things was rendered into English by Trevisa in 1398. There are at least eight manuscripts of this translation..$^{45}$ Polychronicon was written in the early fourteenth century by the English Benedictine Ranulf Higden and survives in over 120 manuscripts belonging to religious houses, institutions, and private laypeople. ${ }^{46}$ Polychronicon was also translated in the later fourteenth century into Middle English by John Trevisa and by another anonymous author in the fifteenth century. There are at least 14 manuscript copies of Trevisa's translation, which was also printed in the early modern peri-

\footnotetext{
43 Chronicles 1.17.

${ }^{44}$ Chronicles 3.6.

${ }^{45}$ Edwards, 'The Text of John Trevisa's Translation', p. 85.

46 Brown, 'Higden's Britain', p. 105.
} 
od. ${ }^{47}$ Both On the Properties of Things and Polychronicon originate with ostensibly English authors. While debatable how 'English' Bartholomaeus was in his own mind, Higden's project claims certain national motivations as a 'treatise gathered of diverse books, of the state of the island of Britain for the knowledge of men who come after us. ${ }^{48}$ While its scope is global, the emphasis is upon England and the imagined audience is clearly English; Higden and his Middle English translators employ the second person. ${ }^{49}$

Both On the Properties of Things and Polychronicon offer prodigious attempts to synthesize vast stores of knowledge from ancient and medieval authorities: in the case of $O n$ the Properties of Things, knowledge about the natural and supernatural world; and in the case of Polychronicon, a universal history of the world up until the author's own present time. Both texts contain extensive sections of geography. On the Properties of Things offers brief descriptions of the geography, customs, animals, plants, and inhabitants of nearly two hundred lands, ranging from Asia to Zeugia. Likewise, Polychronicon also offers an extensive discussion of the divisions of the world, bodies of water, as well as the countries of Africa, Asia, and Europe in the first book.

Modern commentators cite $O n$ the Properties of Things to make various claims about medieval thought on climate and geographical essentialism. Where one study praises the text's descriptions of the Germans and Scots as 'landmarks in the history of anthropological thought', elsewhere it disparages stock phrases in describing the physical appearance and character of other groups. ${ }^{50}$ Such stereotypes include the repetitive choice of adjectives such as 'seemly' to describe bodies, 'steadfast hearts' to describe characters and so on 'invok(ing) repeatedly with the compulsive monotony of the conventional phraseology derived from the old humoral psychology and astrological ethnology. ${ }^{51}$ More recently, a critic argues that these descriptions deliberately sort peoples into their appropriate climate-based groups, creating a binary between European and African, North and South. ${ }^{52}$ The text's discussion of Europe outlines this binary and is often cited in arguments about racial thought in medieval culture:

\footnotetext{
${ }^{47}$ Lavezzo, Angels on the Edge of the World, p. 72.

${ }^{48}$ Higden, Polychronicon, ed. by Babington, I, 6-9.

${ }^{49}$ Lavezzo, Angels on the Edge of the World, p. 72.

${ }^{50}$ Hogden, Early Anthropology in the Sixteenth and Seventeenth Centuries, p. 63.

${ }^{51}$ Hogden, Early Anthropology in the Sixteenth and Seventeenth Centuries, p. 63.

52 Akbari, 'From Due East to True North'.
} 
3if pis partie of pe worlde (Europe) be lesse pan Asia, 3itte is it pere perto in nombre and noblete of men, for as Plius seipe, he fedep men pat ben more huge in bodie, more stronge in my3te and vertue, more bolde of herte, more faire and semeliche of shappe, panne men of the cuntres and londes of Asia oper Africa. For pe sonne abidep [longe] ou[er] pe Affers, men of Affrica, and brennen and wasten humours and maken [ham] short of body, blacke of face, with crispe here. And for spirities passe oute atte pores pat ben open, so pey be more cowardes of herte. And the cuntr[ary]e is of men of pe norpe londe: for coldenes pat is withoute stoppep pe pores and breedep humours of pe bodye makep men more ful and huge; and coolde pat [is] modir of whitnesse makep hem [be] more white in face and [in] skynne, and vapoures and spirities ben ysmyten inwarde and maken hatter withinne and so the more bolde and hardy. An pe men of Asia ben meneliche disposed in pat. ${ }^{53}$

(If this part of the world (Europe) is less than Asia, yet it is peer thereto in number and nobility of men, for as Plius says, he feeds men who are larger in body, stronger in might and virtue, more bold of heart, more fair and seemly of shape, than men of the countries and lands of Asia or of Africa. For the sun abides long over the Affers, men of Africa, and burns and wastes humours and makes them short of body, black of face, with crisp hair. And for spirits pass out at the pores which are open, so they are more cowardly of heart. And the contrary is of men of the north land: for coldness that is without stops the pores and breeds humours of the body which make men fuller and larger; and cold that is mother of whiteness makes them more white in the face and the skin, and vapours and spirits are smitten inward and make them hotter within and so the more bold and hearty. And the men of Asia are meanly disposed in that.)

The passage follows conventional medical theory about the hot and cold complexions, and its positioning of Asia as geographically and physiologically temperate. ${ }^{54}$ One scholar has read his description of Asian character as 'pejorative' in the reference to the people being 'meneliche disposed' (meanly disposed) in Middle English. ${ }^{55}$ However, both 'meneliche' and the original Latin 'mediocriter' likely meant 'moderately'. Then, the context would suggest a humoral balance between the cold qualities of the Africans and the hot qualities of the Europeans. While this passage clearly seems to equate positive qualities with white skin and negative qualities with black skin, this division is not consistent. Elsewhere, in the discussion of the elements, On the Properties of Things describes the characters of people in cold lands which breed 'white men, as among the Slavs':

53 Bartholomaeus Anglicus, On the Properties of Things, ed. by Seymour and others, II, 753.

${ }^{54}$ Biller, 'Proto-Racial Thought in Medieval Science', p. 171.

55 Akbari, 'From Due East to North', p. 24. 
Also coolde is pe modir of whitznesse and of paleness, as hete is pe modir of blaknes and of rednes [...] in coolde londes pe modres of women ben disposed to conseiue suche children. Perfore pey beren children wip whyte skynnes, pat hauep longe, zelew3, neissche, and streite here [...] in pe body per coolde hap pe maistrie pe colour is white, here is neissche and streizt, hard wit and forzeteful, litil appetite, miche slepe, heuy goinge and slowe. ${ }^{56}$

(Also cold in the mother of whiteness and paleness, as heat is the mother of blackness and of redness [...] in cold lands the wombs of the women are disposed to conceive such children. Therefore they bear children with white skins, who have long, yellow, soft and straight hair [...] in the body where cold has mastery the colour is white, the hair soft and straight, the wit dull and forgetful, little appetite, much sleep, heavy going and slow.)

The character of men living in cold lands is certainly more derogatory here, where white skin is associated with dull and forgetful wits, heavy and slow bodies, than in the passage cited relating to Europe and Africa.

At times, the character traits of particular peoples correlate to conventional descriptions of northern peoples; however, climate is rarely invoked, certainly not to same extent as the early modern Method or Chronicles. Where climate is mentioned in reference to particular lands and peoples, it does not relate to character. For example, in the lengthy description of Germany, the large stature and war-like nature of the population are consistent with ancient and conventional climate-based characters. However, the text does not mention the conventional negative characteristics, such as dull wits or rashness, and does not reference climate at all in relation to character. ${ }^{57}$ Rather language and manners are passed on to the English through conquest and colonization.

However, notions of climate in these descriptions of particular lands at times contradict the conventional descriptions On the Properties of Things gives elsewhere. For example, the temperate climate of the Irish, which is not too hot or too cold, would by traditional climatic theory facilitate a temperate population. However, the Irish are described as wild and savage, warriors who drink the blood of the men they kill after washing their faces with it. The text describes their characters:

Men of Irlonde ben singulereliche ycloped and vnsemeliche arraiede and scarseliche yfedde, ful hardy of herte, fers of chiere, angry of speche and sharpe, nopeles freehertede and fayre of speche and godelyche to here own nacioun, and namelyche

56 Bartholomaeus Anglicus, On the Properties of Things, ed. by Seymour and others, I, 136.

57 Bartholomaeus Anglicus, On the Properties of Things, ed. by Seymour and others, II, 732. 
pilke men pat wonen in woodis, marries, and mounteyns. Pise men ben apayede with flesshe, appels, and fruyt for mete, and with mylke for drynke, and zeuen hem for to pleyes and to huntynge pan to worke and trauayle. ${ }^{58}$

(Men of Ireland are uniquely clothed and unseemly arrayed and scarcely fed, full hardy of heart, fierce of cheer, angry and sharp of speech, nonetheless, free-hearted and fair of speech and good to their own country, and namely these men who dwell in the woods, marshes, and mountains. These men are content with flesh, apples and fruit for food, and with milk for drink, and are more given to play and to hunting than to work and travail.)

Here, On the Properties of Things describes a difference of character and behaviour between groups living in Ireland based on their geography; however, the cause is more dietetic than climatic. ${ }^{59}$ This disjuncture between the temperateness of the Irish land and the intemperateness of the Irish people is taken from Gerald of Wales. ${ }^{60}$ However unlike Gerald, On the Properties of Things does not apply this disjuncture to make England more central.

The Scots are depicted in similar terms; namely, because Scots had once settled in Ireland according to the text. However, 'bycause of medlynge with Englisshe men many of hem han changed pe oolde maners of Scottes into bettir maners for pe more deele' (because of mixing with English men, many of them have changed the old manners of Scots into better manners for the most part).$^{61}$ What does On the Properties of Things mean by 'mixing' or 'medlyng' as it is rendered in Trevisa's translation? It could mean either association or breed-

58 Bartholomaeus Anglicus, On the Properties of Things, ed. by Seymour and others, II, 769.

59 Bartholomaeus Anglicus, On the Properties of Things, ed. by Seymour and others, II, 769.

${ }^{60}$ Gerald writes that Ireland is 'the most temperate of all countries', enjoying 'the freshness and mildness of spring almost all the year round' and meaning that 'the air is so healthy that there is no disease-bearing cloud, or pestilential vapour, or corrupting breeze'. Gerald of Wales, History and Topography of Ireland, p. 53. This temperate climate and lack of disease stands in utter contrast to the people described. However, Gerald shows social and cultural causes for the disjunction. 'But although they are fully endowed with natural gifts, their external characteristics of beard and dress, and internal cultivation of the mind, are so barbarous that they cannot be said to have any culture'. (p. 101) He emphasizes their marginality as factoring into their barbarity: 'All their habits are the habits of barbarians. Since conventions are formed from living together in society, and since they are so removed in these distant parts from the ordinary world of men, as if they were in another world altogether and consequently from well-behaved and law-abiding people, they know only of the barbarous habits in which they were born and brought up, and embrace them as another nature. Their natural qualities are excellent. But almost everything acquired is deplorable' (pp. 102-03).

${ }^{61}$ Bartholomaeus Anglicus, On the Properties of Things, ed. by Seymour and others, II, 812. 
ing. Regardless, the possibility for the Scots to adapt emphasizes a learned, sociocultural force over essentialist, climatic theory.

Other northern lands and peoples, such as Norwegians, Saxons, and particularly Swedes, are praised for bravery and skill in battle. Although he overcame the French, Germans and Britons, Julius Caesar 'dredde to fyghte with Danes, Gootes, Norweyes, and opere men of pe northe' (dreaded to fight with Danes, Goths, Norwegians and other men of the north). ${ }^{62}$ Not all Northerners fare so well. The Slavs are described as 'fers and sharpe and vnsemelich, wipoute deuocioun in Goddis seruice, and lede pe lyf of skymmours and see peves' (fierce and sharp and unseemly, without devotion in God's service living the life of pirates). ${ }^{63}$ However, in 'lesse Sclauia' (lesser Slavia) the people are 'stronge of body, erthe tilliers an fisshers, and more deuoute to Godde and peisible to neyzbores panne pilke pat wonen in pe more Sclauia' (strong of body, farmers and fishers, and more devout to god and peaceful to neighbours than those who dwell in greater Slavia). ${ }^{64}$ The distinction between the two groups of Slavs owes to the 'medlynge and companye pat peu haue alle day with pe Germans' (mixing and company that they have all day with the Germans). ${ }^{65}$ Although citing an ancient source here (Herodatus), it is surprising that $O n$ the Properties of Things does not make a reference to earlier physiological argument. After all, we recall, the Slavs were the quintessential 'white men' used to describe the influence of cold climates and cold physiologies. Instead, the text relies solely on socio-cultural influences upon character rather than climate theory. Although certainly prejudiced in favour of certain groups of people that might exercise a certain paternalistic benefit to other groups, the nature of this prejudice does not appeal to science, or at least, does not appeal to climate theory. Furthermore, far from carefully delineating what is north and what is south, what is east and what is west, On the Properties of Things rarely used cardinal directions as descriptors. Beyond general descriptions of northern and southern climate-based temperaments, there is little reference to climate in the text's descriptions of particular lands.

Given the particularly English context and motive behind the text, what is the role of climate in shaping character and specifically northern and English characters in Polychronicon? Polychronicon consists of seven books, the first of

62 Bartholomaeus Anglicus, On the Properties of Things, ed. by Seymour and others, II, 813.

${ }^{63}$ Bartholomaeus Anglicus, On the Properties of Things, ed. by Seymour and others, II, 806.

${ }^{64}$ Bartholomaeus Anglicus, On the Properties of Things, ed. by Seymour and others, II, 807.

${ }^{65}$ Bartholomaeus Anglicus, On the Properties of Things, ed. by Seymour and others, II, 807. 
which concerns world geography with the bulk devoted to Britain. This geographical section was particularly popular as evidenced by its circulation independently from the rest of the text. ${ }^{66}$

Although dividing the world traditionally in its traditional three parts Asia, Europe and Africa - Polychronicon focuses on Europe and Africa in terms of climate and character. Africa and Europe were once thought to have been joined, but Africa was cut off like 'a sore membre pat is nouzt from membres at pat beep hole' (a sore limb from whole members) due to its 'yuel doers, corrupte ayre, wylde bestes and venomous wonep perynne' (evil doers, corrupt air, wild and venomous beasts). ${ }^{67}$ Furthermore, the text draws upon the familiar climatic logic that the boldness and heartiness characteristic to Northerners results from the external cold trapping the heat within. Although 'all pat lyueth and growep may better endure wip colde pan wip hete; bote mesure rule bope' (all who live and grow may better endure with cold than with heat, but measure rules both), little attention is given to measure or its implied geography and climate, presumably Asia. Instead Europe is shown to produce 'men huger and gretter of body, my3tier of strengpe, hardier and bolder of herte, and fairer of schap, pan men of Affrica' (men larger and greater of body, mightier of strength, hardier and bolder of heart and fairer of shape than Africa). ${ }^{68}$ The hot sun in Africa affects the body in similar ways to those described previously, drawing out the humours and causing cowardice. In contrast are 'norperen men, in pe whiche colde wip oute stoppep smale holes and poorus, and holdep the hete wip wynne; and so makep hem fatter, gretter, and whitter and hatter with inne, and so hardier and boldere of herte' (northern men in which the cold outside blocks small holes and pores and holds the heat within, and so makes them fatter, greater, and whiter and hotter within, and so hardier and bolder of heart). ${ }^{69}$ General statements about climate and character are sprinkled throughout the text. For example, 'by pe dyuersite of heuene is dyuersite of colours of face, of quantite and gretnes of body, of maneres and of witt; perfore in Rome beep heuy men, yn Grees lyzt, in Affrica gileful, in Gallia witty men and wyse' (by the diversity of heaven is diversity of facial colours, of quantity and greatness of body, of manners and of wit; therefore, in Rome men are heavy; in Greece, light; in Africa, guileful; and in France, witty and wise). ${ }^{70}$

${ }^{66}$ Brown, 'Higden's Britain', p. 106.

${ }^{67}$ Higden, Polychronicon, ed. by Babington, I, 51.

${ }^{68}$ Higden, Polychronicon, ed. by Babington, I, 51-52.

${ }^{69}$ Higden, Polychronicon, ed. by Babington, I, 53.

${ }^{70}$ Higden, Polychronicon, ed. by Babington, I, 267. This statement is repeated in abbreviated form, p. 295. 
However, beyond these general statements of physiological superiority over the Africans, how does Higden express the relationship of climate specifically to the character of people of England and in other northern lands? There is one particularly important example of the impact of climate on history. Speaking of Germany, Polychronicon explains that being far from the sun, the northern lands are healthy and enable reproduction easily much more than in southern lands. ${ }^{71}$ This ease of reproduction means, however, that Germany produces more children than it can sustain. The text uses this physiological knowledge to establish why people from this part of the world conquer other lands. There are very few other references to how the northern climate shapes attendant physiology and character. Comparing them to the snow melting on their native Alps, the text relates that the French are hasty and strong at first then their courage begins to falter with the heat of the sun or once they break out in a sweat. ${ }^{72}$ Also, the Flemish character is attributed to two causes: mixing with the French and the climate which makes them 'stronge of body, faire of face, bold of herte, and fel of witte' (strong of body, fair of face, bold of heart and treacherous of wit). ${ }^{73}$ However, the invocation of climate here seems opportunistic. No reference to a climatically degraded wit occurs in descriptions of other northern peoples much more northerly than Flanders.

In describing northern character formation, the text more often points to mixing with other groups. The text lists positive qualities of Danes familiar to those of other northern peoples: 'beep faire of stature and semeliche of face and of here. And pouz pey be sterne azenst here enemyes, pey beep to gode men and trewe bope esy and mylde' (are of elegant stature, having attractive face and hair. And although they are stern against their enemies, they are easily and mild to good and true men). However, the text continues: 'but pat may not be forzete, pat pey brouzte grete drynkynge into Engelond' (let it not be forgotten that they brought excessive drinking to England). ${ }^{74}$ Where early modern texts clearly explain excessive northern drinking habits as part of their physiological impulse, here it is clearly a custom that is transmitted by exposure to other groups.

${ }^{71}$ Higden, Polychronicon, ed. by Babington, I, 255.

${ }^{72}$ Higden, Polychronicon, ed. by Babington, I, 269. This sentiment is not unique to Polychronicon. Albert the Great writes that 'the French, who want to do wondrous things at the beginning and in the end accomplish nothing, and people like this are called hardi (bold) in French'; cited in Resnick, Marks of Distinction, p. 308.

${ }^{73}$ Higden, Polychronicon, ed. by Babington, I, p. 295.

${ }^{74}$ Higden, Polychronicon, ed. by Babington, I, 323. 
Like Gerald of Wales, the text both includes the healthiness and temperateness of the Irish climate and the barbarity of the people. However, the contrast is not made explicitly in Polychronicon as it is in Gerald of Wales. Negative aspects of their character - sloth and idleness, bad manners, failure to tithe or lawfully wed, variability, treachery, and so on - are rather given a socio-cultural rather than climatic causality. Indeed, 'aliens and men of straunge londes pat wonep longe among hem drawep aftir pe manere of hir companye' (men of foreign lands who dwell long among them take after the manner of their company), meaning that they fall into 'schrewednesse and bycomep traytours' (shrewdness and become traitors). ${ }^{75}$ The Irish have also influenced the Scots in terms of their 'in her byleue, in clopinges, in langage, in speche, in wepene, and in maneres' (beliefs, clothing, in language, in speech, in weapons, and in manners) through intermarriage. ${ }^{76}$

Yet the initial Irish influence on the Scottish temperament has been mitigated by 'mixing' with the English: 'Scottes beep lyzt of herte, strange and wylde i-now, but by mellynge of Englisch men pey beep moche amended' (Scots are light of heart, strange and wild' yet 'by mixing with English men they are much amended). ${ }^{77}$ Trevisa's Middle English translation uses 'mellynge' and the Latin 'admixtione'. Rather than conceived as a matter of climatically determined essentialism, northern characters seem adaptable through cultural osmosis. Likewise, group behaviour adapts to changes in financial circumstance. For example, the text remarks that the Welsh now behave more like English men than in the past. They are more peaceful, because they now have more to lose by starting conflicts. ${ }^{78}$

While the English are compared favourably to the Scots and the Irish as they are in early modern descriptions, their difference is not essential. Furthermore, Higden's division of his own country, while allowing diversity of character by geographical division does not invoke climate either:

Men of pe soup beep easier and more mylde; and men of pe north be more vnstable, more cruel, and more vnesy; pe myddel men beep somdele partyners wip bope: also pey wonep hem to glotonye more pan oper men, and beep more costlewe in mete

\footnotetext{
75 Higden, Polychronicon, ed. by Babington, I, 357-59.

${ }^{76}$ Higden, Polychronicon, ed. by Babington, I, 385.

77 Higden, Polychronicon, ed. by Babington, I, 387-89.

${ }^{78}$ Higden, Polychronicon, ed. by Babington, I, 411.
} 
and in drynke and in clopynge. Me trowep pat pey took pat vyce of kynge Hardeknute pat was a Dane. ${ }^{79}$

(The people of the south are more meek and quiet, the people of the north are more inconstant and cruel, the people of the middle parts share these qualities. Also the people of England are given more to gluttony and excess before other people, expending much money in meat and clothes. I believe that they took that vice from King Hardenknute who was a Dane).

While these conventional characteristics are in early modern texts attributed to climate and medical essentialism, Trevisa and Higden do not make these connections here. Furthermore, the reference to King Hardenknute's legacy suggests an entirely different way that behaviour and character is transmitted.

Unlike the early modern texts, in the medieval encyclopaedic texts we find less interest in geographical boundaries and their climatic implications. It is unclear where North begins and ends in either De proprietatibus rerum or Polychronicon, what North includes and excludes. Rather the discourse of 'north' exists more commonly in other English texts within the blend of the biblical reference to Lucifer sitting in the North and traditional northern European legends of the mythical goddess Hel who lived in the North. For example, in Piers Plowman, Lucifer takes residence in the North, and in Gawain and the Green Knight, Gawain makes a pilgrimage northward to battle a green giant. Sermons sometimes also position hell in the North. For example, in Dublin, Trinity College, MS 241, the faithful are urged to focus the eyes of the soul north to hell, east to heaven, west to the start of life, and south to the end of life $\left(\right.$ fol. $\left.85^{v}\right)$. Such a view of the North is more consistent with the tales of the fabulous seen elsewhere in the volume. Within medieval English culture, the North is still a land apart, 'strange and wild', less medically than mythically conceived. England, too, is a land apart. However, it is unclear where and wither England and North merge.

${ }^{79}$ Higden, Polychronicon, ed. by Babington, II, 167. 


\section{Works Cited}

\section{Primary Sources}

Aquinas, Thomas, De regno ad regem Cypri: On Kingship to the King of Cyprus, trans. by Gerald B. Phelan, rev. by I. Th. Eschmann (Toronto: Pontifical Institute of Mediaeval Studies, 1949); available online at <http://dhspriory.org/thomas/DeRegno.htm> [accessed 20 September 2017]

Bartholomaeus Anglicus, On the Properties of Things: John Trevisa's Translation of Bartholomaeus Anglicus's 'De proprietatibus rerum'. A Critical Text, ed. by M. C. Seymour and others, 3 vols (Oxford: Clarendon Press, 1975-88)

Bodin, Jean, Method for the Easy Comprehension of History, trans. by Beatrice Reynolds (New York: Columbia University Press, 1945)

- Methodus ad facilem historiarum cognitionem (Geneva: Jacobum Stoer, 1610)

Gerald of Wales, History and Topography of Ireland, trans. by John J. O’Meara (New York: Penguin, 1982)

Higden, Ranulf, Polychronicon Ranulphi Higden monachi Cestrensis; Together with the English Translations of John Trevisa and of an Unknown Writer of the Fifteenth Century, ed. by Churchill Babington (London: Longman, Green, Longman, Roberts, and Green, 1865)

Holinshed, Raphael, Chronicles of England, Scotland and Ireland <http://www.cems. ox.ac.uk/holinshed/texts.shtml> [accessed 20 September 2017]

\section{Secondary Works}

Akbari, Suzanne Conklin, 'From Due East to True North: Orientalism and Orientation', in The Post-Colonial Middle Ages, ed. by Jeffrey Jerome Cohen (New York: Palgrave Macmillan, 2000), pp. 19-34

Bartlett, Robert, 'Medieval and Modern Concepts of Race and Ethnicity', Journal of Medieval and Early Modern Studies, 31.1 (2001), 39-56

- 'Symbolic Meanings of Hair in the Middle Ages', Transactions of the Royal Historical Society, 6th ser., 4 (1994), 43-60

Beller, Manfred, 'Climate', in Imagology: The Cultural Construction and Literary Representation of National Characters. A Critical Survey, ed. by Manfred Beller and Joep Leerssen (Amsterdam: Rodopi, 2007), pp. 298-304

Biller, Peter, 'Proto-Racial Thought in Medieval Science', in The Origins of Racism in the West, ed. by Miriam Eliav-Feldon, Benjamin Isaac, and Joseph Ziegler (Cambridge: Cambridge University Press, 2013), pp. 157-80

Brown, Peter, 'Higden's Britain', in Medieval Europeans: Studies in Ethnic Identity and National Perspectives in Medieval Europe, ed. by Alfred P. Smyth (New York: Palgrave, 1998), pp. 103-18

Burke, Marshall, Solomon M. Hsiang, and Edward Miguel, 'Climate and Conflict', National Bureau of Economic Research, NBER Working Paper No. 20598 (2014) <http://www.nber.org/papers/w20598> [accessed 20 September 2017] 
Cohen, Jeffrey Jerome, 'On Saracen Enjoyment: Some Fantasies of Race in Late Medieval France and England', Journal of Medieval and Early Modern Studies, 31 (2001), $113-46$

—, 'Race', in A Handbook of Middle English Studies, ed. by Marion Turner (Oxford: Wiley, 2013), pp. 109-22

Dean, Leonard F., 'Bodin's “Methodus" in England before 1625', Studies in Philology, 39.2 (1942), 160-66

Edwards, A. S. G., 'The Text of John Trevisa's Translation of Bartholomaeus Anglicus' De Proprietatibus Rerum', Text, 15 (2003), 83-96

Feerick, Jean, 'A “Nation...Now Degenerate”: Shakespeare's Cymbeline, Nova Brittania, and the Role of Diet and Climate in Reproducing Races', Early American Studies: An Interdisciplinary Journal, 1 (2003), 30-71

Floyd-Wilson, Mary, 'Temperature, Temperance, and Racial Difference in Ben Jonson's The Masque of Blackness', English Literary Renaissance, 28.2 (1998), 183-209

Floyd-Wilson, Mary, and Garrett A. Sullivan, Jr, eds, Environment and Embodiment in Early Modern England (Basingstoke: Palgrave Macmillan, 2007)

Glacken, Clarence J., Traces on the Rhodian Shore: Nature and Culture in Western Thought from Ancient Times to the End of the Eighteenth Century (Berkeley: California University Press, 1967)

Heng, Geraldine, 'The Invention of Race in the European Middle Ages I: Race Studies, Modernity and the Middle Ages', Literature Compass, 5 (2011), 258-74

- 'The Invention of Race in the European Middle Ages II: Locations of Medieval Race', Literature Compass, 5 (2011), 275-93

Hogden, Margaret T., Early Anthropology in the Sixteenth and Seventeenth Centuries (Philadelphia: University of Pennsylvania Press, 1964)

Isaac, Benjamin, 'Racism: A Rationalization of Prejudice in Greece and Rome', in The Origins of Racism in the West, ed. by Miriam Eliav-Feldon, Benjamin Isaac, and Joseph Ziegler (Cambridge: Cambridge University Press, 2013), pp. 32-56

Knapp, Jeffrey, An Empire Nowhere: England, America, and Literature from Utopia to the Tempest (Berkeley: University of California Press, 1991)

Langum, Virginia, Medicine and the Seven Deadly Sins in Late Medieval Literature and Culture (New York: Palgrave Macmillan, 2016)

—, 'Sacred and Secular Wrath in Medieval English Sources', in The Sacred and the Secular in Medieval Healing: Sites, Objects, and Texts, ed. by Barbara S. Bower and Linda Migl Keyser (New York: Routledge, 2016), pp. 13-25

Lavezzo, Kathy, Angels on the Edge of the World: Geography, Literature, and English Community (Ithaca: Cornell University Press, 2006)

Livingstone, David N., 'Race, Space and Moral Climatology: Notes Toward a Genealogy', Journal of Historical Geography, 28.2 (2002), 159-80

MacInnes, Ian F., 'Altering a Race of Jades: Horse Breeding and Geohumoralism in Shakespeare', in Horse as Cultural Icon: The Real and Symbolic Horse in the Early Modern World, ed. by Peter Edwards and others (Leiden: Brill, 2011), pp. 173-89

Nisbett, Richard, and Dov Cohen, Culture of Honor: The Psychology of Violence in the South (Boulder: Westview Press, 1996) 
Partonen, Timo, and Andres Magnusson, Season Affective Disorder: Practice and Research (Oxford: Oxford University Press, 2001)

Ranson, Matthew, 'Crime, Weather and Climate Change', Journal of Environmental Economics and Management, 67.3 (2014), 274-302

Resnick, Irven M., Marks of Distinction: Christian Perceptions of Jews in the High Middle Ages (Washington, DC: Catholic University Press of America, 2012)

Tilman, Jean Paul, An Appraisal of the Geographical Works of Albertus Magnus and his Contributions to Geographical Thoughts (Ann Arbor: University of Michigan Press, 1971)

Tooley, Marian J., 'Bodin and the Medieval Theory of Climate', Speculum, 28 (1953), 64-83

Van de Vliert, Shalom H. Schwartz, and others, 'Temperature, Cultural Masculinity, and Domestic Political Violence: A Cross-National Study', Journal of Cross-Cultural Psychology, 30.3 (1999), 291-314

Wands, John, 'The Theory of Climate in the English Renaissance and Mundus Alter et Idem', Medieval and Renaissance Texts and Studies, 38 (1986), 519-29

Zacharasiewicz, Waldemar, 'The Theory of Climate and the North in Anglophone Literature', in Images of the North: Histories - Identities - Ideas, ed. by Sverrir Jakobsson (Amsterdam: Rodopi, 2009), pp. 25-47

Ziegler, Joseph, 'Physiognomy, Science and Proto-Racism, 1200-1500', in The Origins of Racism in the West, ed. Miriam Eliav-Feldon, Benjamin Isaac, and Joseph Ziegler (Cambridge: Cambridge University Press, 2013), pp. 181-99 